\begin{tabular}{|c|c|c|}
\hline $\begin{array}{l}\text { 2. To: (Receiving Organization) } \\
\text { DISTRIBUTION }\end{array}$ & $\begin{array}{l}\text { 3. From: (Originating Organization) } \\
\text { SPECIAL ANALYTICAL SUPPORT } \\
8 \mathrm{C} 530\end{array}$ & $\begin{array}{l}\text { 4. Related EDT No.: } \\
\text { N/A }\end{array}$ \\
\hline $\begin{array}{l}\text { 5. Proj./Prog./Dept./Div.: } \\
\text { VAPOR/AS/SPECIAL/ANALYTICAL/ } \\
\text { SUPPORT }\end{array}$ & $\begin{array}{l}\text { 6. Design Authority/ Design Agent/Cog. } \\
\text { Engr.: } \\
\text { RICKY MAHON 3-7437 }\end{array}$ & $\begin{array}{l}\text { 7. Purchase Order No.: } \\
\qquad N / A\end{array}$ \\
\hline \multirow{2}{*}{\multicolumn{2}{|c|}{$\begin{array}{l}\text { 8. Originator Remarks: } \\
\text { SST-241-C-201. SAMPLING USING THE VAPOR SAMPLING SYSTEM }\end{array}$}} & $\begin{array}{l}\text { 9. Equip./Component No.: } \\
\mathrm{N} / \mathrm{A}\end{array}$ \\
\hline & & $\begin{array}{c}\text { 10. System/Bldg./Facility: } \\
622 G \\
\end{array}$ \\
\hline \multirow[t]{3}{*}{ 11. Receiver Remarks: } & \multirow[t]{3}{*}{ Basel ine Document? [] Yes $[X]$ No } & $\begin{array}{l}\text { 12. Major Assm. Dwg. No.: } \\
\qquad \mathrm{N} / \mathrm{A}\end{array}$ \\
\hline & & $\begin{array}{l}\text { 13. Permit/Permit Application No.: } \\
\text { N/A }\end{array}$ \\
\hline & & 14. Required Response Date: \\
\hline
\end{tabular}

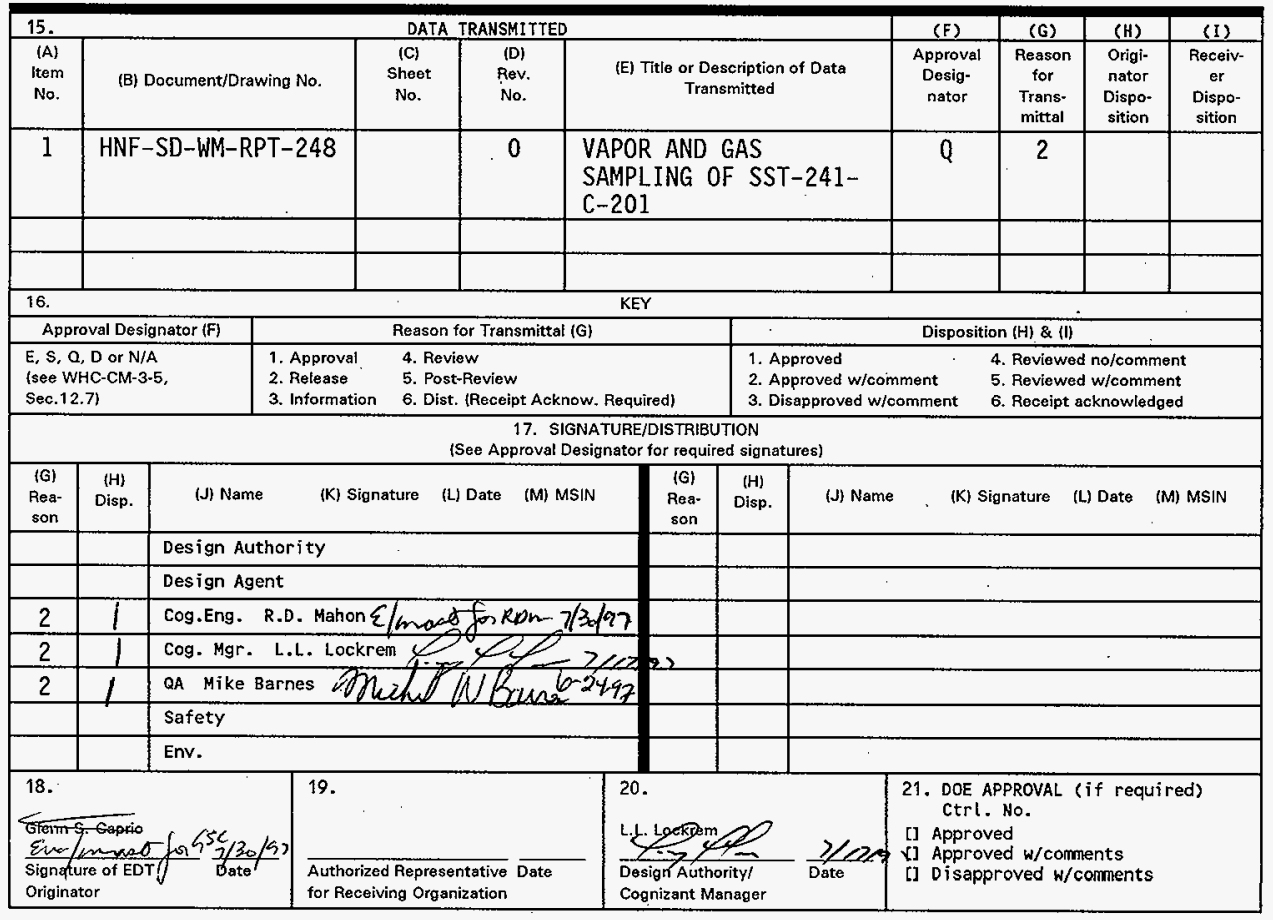




\section{VAPOR AND GAS SAMPLING OF SINGLE-SHELL TANK 241-C-201 USING the in Situ Vapor Sampling System}

\section{G.S. Caprio}

SGN Eurisys Services Company, Richland, WA 99352

U.S. Department of Energy Contract DE-AC06-96RL13200
EDT/ECN: 621267
Org Code: 8 C530
UC: 2070
B\&R Code: EW3120074
Charge Code: $E 62000$
Total Pages: 31

Key Words: 241-C-201, ISVS, SUMMA'M, TST, SORBENT, TANK

Abstract: THIS DOCUMENT PRESENTS SAMPLING DATA RESULTING FROM THE JUNE 19, 1996 SAMPLING OF SST 241-C-201

TRADEMARK DISCLAIMER. Reference herein to any specific commercial product, process, or service by trade name, tradenark, manufacturer, or otherwise, does not necessarily constitute or imply its endorsement, recommendation, or favoring by the United States Government or any agency thereof or its contractors or subcontractors.

Printed in the United States of America. To obtain copies of this document, contact: Document Control Services, P.O. Box 950, Mailstop H6-08, Richland WA 99352, Phone (509) 372-2420;

Fax (509) 376-4989.
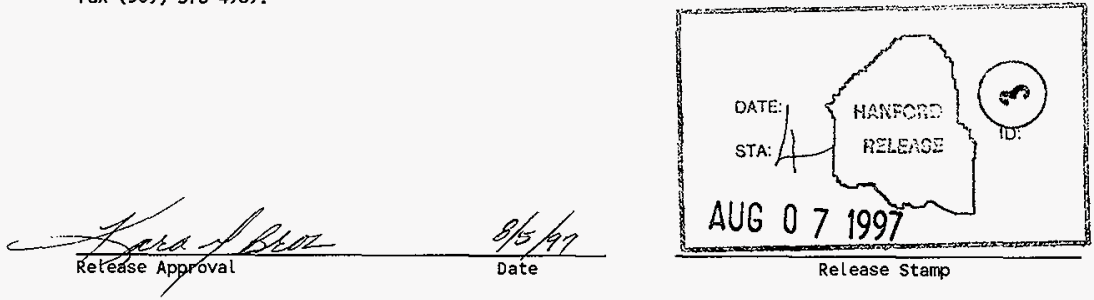

\section{Approved for Public Release}


HNF-SD-WM-RPT-248，Rev . 0

APPROVALS

Document title:

Vapor and Gas. Sampling of Single-Shell Tank 241-C-201

Using the In Situ Vapor Sampling System

Approved by :

G. S. Caprio, Field Scientist

Date

Vapor Sampling Project

Special Analytical studies

Approved by:

Approved by:

R. D. Mahon, Project Lead

Date Vapor Sampling Project

Special Analytical Studies

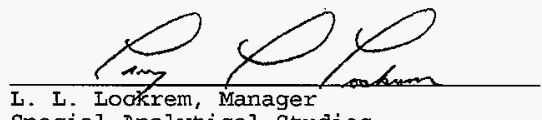


CONTENTS

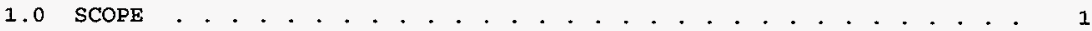

2.0 SAMPLING EQUIPMENT DESCRIPTION . . . . . . . . . . . . . . . . . . . 1

2.1 IN SITU VAPOR SAMPLING SYSTEM . . . . . . . . . . . . . . . . . 1

3.0 SAMPLING EVENT DESCRIPTION . . . . . . . . . . . . . . . . . . . . 2

3.1 SPECIFICATIONS........... .22

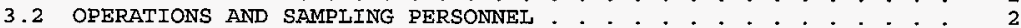

3.3 INDUSTRIAI HYGIENE FIELD RESULTS . . . . . . . . . . . . . . . . 2

3.4 AMBIENT CONDITIONS . . . . . . . . . . . . . . 3

3.5 SAMPLE COLLECTION . . . . . . . . . . . . . . . . . . . . . . . 3

3.6 RADIATION SCREENING . . . . . . . . . . . . . . . . . 3

4.0 SAMPLE CHAIN OF CUSTODY: RECEIPT, STORAGE, AND SHIPMENT . . . . . 4

5.0 QUALITY ASSURANCE AND CONTROLS . . . . . . . . . . . . . . . . . 5

5.1 CLEANLINESS OF SYSTEM . . . . . . . . . . . . . . . . . . . . . 5

5.2 INSTRUMENT CALIBRATION . . . . . . . . . . . . . . . . . . . . 5

5.3 BLANK SAMPLES . . . . . . . . . . . . . . . . . . . . 6

6.0 ANOMALIES . . . . . . . . . . . . . . . . . . . . . 6

7.0 REFERENCES . . . . . . . . . . . . . . . . . . . . . . . 7

APPENDICES

SAMPLE LOG SHEETS . . . . . . . . . . . . . . . . . . . . . A-1

AMBIENT CONDITIONS . . . . . . . . . . . . . . . . . . . . . B-1

CHAIN-OF-CUSTODY FORMS . . . . . . . . . . . . . . . . . . C-1 
HNF -SD-WM-RPT-248，Rev，0

\section{IIST OF TABLES}

1. Radionuclide Analysis Results. . . . . . . . . . . . . . . . . 4

2. Calibration Data . . . . . . . . . . . . . . . . . 5

3. Totalizer Calibration Data . . . . . . . . . . . . . . 6 


$$
\begin{aligned}
& \text { CGI } \\
& \text { COC } \\
& \text { DOT } \\
& \text { GEA } \\
& \text { ISVS } \\
& \mathrm{NH}_{3} \\
& \mathrm{H}_{2} \mathrm{O} \\
& \text { OPC } \\
& \text { OVM } \\
& \text { PNNL } \\
& \text { SAS } \\
& \text { SHA } \\
& \text { SMI } \\
& \text { SST } \\
& \text { TCP } \\
& \text { TOC } \\
& \text { TST } \\
& \text { VT } \\
& \text { WHC } \\
& \text { WSCF }
\end{aligned}
$$

Combustible Gas Indicator

Chain of Custody

U.S. Department of Transportation

Gamma Energy Analysis

In Situ Vapor Sampling system

Ammonia

Water Vapor

Offsite Property Control

Organic Vapor Meter

Pacific Northwest National Laboratory

Special Analytical studies

Sample Head Assembly

Sampling and Mobile Laboratories

Single-Shell Tank

Tank Characterization Plan

Total Organic Carbon

Triple Sorbent Trap

Vapor Team, personnel from Sampling and Mobile Laboratories and Special Analytical Studies Westinghouse Hanford Company

Waste Sampling and Characterization Facility 
HNF - SD-WM-RPT-248，Rev. 0

This page intentionally left blank. 
HNF - SD - WM-RPT-248, Rev . 0 VAPOR AND GAS SAMPLING OF SINGLE-SHELL TANK 241-C-201
USING THE IN SITU VAPOR SAMPLING SYSTEM

\subsection{SCOPE}

The Vapor Issue Resolution Program tasked the Vapor Team (VT) to collect representative headspace samples from Hanford site single-shell tank (SST) 241-C-201. This document presents In Situ Vapor Sampling System (ISVS) data resulting from the June 19, 1996 sampling of SST 241-C-201. Analytical results will be presented in separate reports issued by the Pacific Northwest National Laboratory (PNNL) which supplied and analyzed the sample media.

\subsection{SAMPLING EQUIPMENT DESCRIPTION}

\subsection{IN SITU VAPOR SAMPLING SYSTEM}

The VT, consisting of Sampling and Mobile Laboratories (SMI) and Special Analytical Studies (SAS) personnel, used the IsVS to collect representative samples of the air, gases, and vapors from the headspace of SST 241-C-201 on June 19, 1996. WHC-SD-WM-SDD-068 Rev. 0, System Design Description for the In Situ Vapor Sampling System (Blanchard 1996a) describes, in detail the ISvS performance, its characteristics, and its operation.

In situ sampling is a method designed to collect vapor samples of the homogeneous headspace of waste tanks. Sample media, consisting of sorbent traps and radiological filters, are lowered into the tank headspace. Tank gases are drawn through the media by means of the Isvs manifold, which measure the volume of gas drawn through the system. The sample media are collected together in a sample head assembly (SHA). The SHA provides for twelve sorbent or triple sorbent trap (TST) samples (single sample each) to be sampled in sets of four, one SUMMA sampling line, and one line for radiological filtration.

The SHA is protected from external contamination and breakage by a transparent plastic tube. The plastic tube is cut, formed, and connected to the SHA. The plastic tube also prevents any part of the SHA from accidentally falling into the tank.

A set of $1 / 4$ or $5 / 16$ inch diameter flexible tubes, approximately 50 feet Iong, are held together with spiral wrap to form a "tube bundle", which connects the ISVS to the SHA. The tube bundle and SHA are assembled prior to sampling and are referred to as the "sample assembly".

Sorbent traps are pencil-size stainless steel or glass tubes that contain vapor-adsorbing media. The sorbent traps may be used singly or may be prepared with several individual traps joined in series (a sorbent train). $A$ known amount of sample vapor is passed through the tube, which traps (by adsorption) virtually all the target analytes. The concentration of analytes in the vapor sampled is calculated from the quantity of analyte found in the sorbent media and the volume of vapor passed through the sorbent trap. In addition to the sorbent traps, SUMMA canisters are also used to collect samples.

SUMMA" canisters are stainless steel vessels with internal surfaces that have been prepared by the SUMMA" process, which passivates active sites on the canister walls to minimize adsorption of gases and vapors. An analytical laboratory must clean and evacuate SUMMA canisters before each use. The 
HNF - SD - WM-RPT-248, Rev. 0

evacuated canister is filled with sample vapor through a valve, which is then closed to seal the sample inside. SUMMA canisters allow collection and transfer of whole-air samples from location to an analytical laboratory where the sample is analyzed. The standard capacity of each SUMMA" canister is 6 liters.

The ISVS consists of five sample stations, (four for sorbent trap sampling and one for SUMMA" sampling) terminating in 1/4 inch outside diameter stainless steel tubing. Each sorbent sample station is independently operable at the selected flow rate, from 50 to 500 standard cubic centimeters per minute (sccm) .

The system is a portable sampling system. It is designed to allow setup and preparation to be performed outside of the tank farm, with a minimum number of steps to be performed inside the farm. It operates on $110 \mathrm{~V}$ AC power. The ISVS was designed to meet the requirements of National Fire Protection Association 70 - 1993 (the National Electrical Code) for general industrial use. Before the ISVS can be used in any tank, procedures require a flammability check of the waste tank which shows that concentrations of flammable materials are well below lower flammability limits.

Tank gases passing through the ISvS will either pass through a sorbent trap and then a backup line dryer, or through the on-board activated charcoal/drierite cartridge. A check valve is installed in the system to prevent any possibility of siphoning materials into the waste tanks.

\subsection{SAMPIING EVENT DESCRIPTION}

\subsection{SPECIFICATIONS}

The Vapor Issue Resolution Program specifies sampling requirements in WHC-SD-WM-TP-335 Rev, 2A, Vapor Sampling and Analysis Plan (Homi 1996b). The Sampling and Analysis Plan also specifies the types and number of samples to be collected, flow rates, and durations. These key sampling parameters are summarized on the sample log sheets in Appendix A. In addition to the sample log sheets, checksheets for each individual sample help ensure correct sampling procedures. The VT retains these documents in the project file. The project specific number for this sampling event is S6-065.

\subsection{OPERATIONS AND SAMPLING PERSONNEL}

Steve Carter was the Tank Farm Operations person-in-charge. The VT members included:

G. S. Caprio, Field Scientist

R. D. Mahon, Lead Scientist

C. S. McClellan, Sampling Technician.

The ISVS was set up at SST 241-C-201 on June 19, 1996 and was allowed to warm up for approximately 15 minutes. Sampling began at approximately 1220 on June 19, 1996, and was completed by 1510 the same day.

\subsection{INDUSTRIAL HYGIENE FIELD RESULTS}

Prior to inserting the tube bundle into SST 241-C-201, an industrial hygiene technician field tested tank vapors. The technician purged the instrument with tank gas for 5 minutes and then field measured vapor stream contents 
HNE - SD-WM-RPT-248，Rev. 0

using a combustible gas indicator (CGI) and an organic vapor meter (OVM). The technician measured the tank vapors at the breather filter, three feet down the xisex, and twenty-six feet down the riser. The measurements reported at the breather filter: LEL $0 \%, \mathrm{NH}_{3} 0.0 \mathrm{ppm}, \mathrm{O}_{2} 20.9 \%$, HCN $0 \%$, and TOC $0.5 \mathrm{ppm}$. The measurements approximately three feet down were: LEL $0.0 \%, \mathrm{NH}_{3} 0 \mathrm{ppm}, \mathrm{O}_{2}$ $20.9 \%$, and TOC $0.5 \mathrm{ppm}$. The measurements approximately twenty-six feet down were: LEL $0.0 \%, \mathrm{NH}_{3} 0 \mathrm{ppm}, \mathrm{O}_{2} 20.9 \%$, and TOC $0.5 \mathrm{ppm}$.

\subsection{AMBIENT CONDITIONS}

The weather the day of the sampling event, June 19, 1996, was sunny and clear. Graphs of ambient temperatures and pressures taken at the Hanford

Meteorological Station, which is about 6 miles west of C-Farm, are provided in Appendix B .

\subsection{SAMPLE COELECTION}

One analytical laboratory provided sample media. PNNL provided SUMMA" canisters, sorbent traps for organic vapors, ammonia $\left(\mathrm{NH}_{3}\right), \mathrm{NO}_{\mathrm{X}}$, and water vapor $\left(\mathrm{H}_{2} \mathrm{O}\right)$.

The VT began inserting the sample media into the SHA at 1615 on June 18, 1996, and finished at approximately 1845. The SHA was connected to tube bundle $14 \mathrm{~A}$. The top collar as described in ECN \#632433 was used for this sampling event. The sample assembly was txansported to $241-\mathrm{C}-201$ on June 19, 1996, and connected to ISVS \#1 for the sampling event.

Prior to sample collection, a leak check of the ISvs sampling manifold and transfer tubing was performed. Pressure gauge readings were recorded at the beginning of the leak check. The gauge readings were used for the leak check calculations but for report purposes will be converted to absolute pressure. The system was evacuated to approximately $118.5 \mathrm{mbar}(3.5 \mathrm{inHg}$ ) and leakage of ambient air into the system was observed by monitoring system pressure for 5 minutes. Leakage resulted in an increase of 0 mbar $(0 \mathrm{inHg})$ in system pressure during the 5 minute test.

The tank flange was opened and the tube bundle was lowered 7.92 meters (26 feet). Tank vapor was drawn through each TST, sorbent, and SUMMA" Iine for a specified period of time. Appendix A indicates the exact times and volumes of tank gas that was drawn through each sample.

After the final sample was collected the sample assembly was removed from the tank. Plugs were placed between 1440 and 1500 hours in the $c$-flex inlets and c-flex clamps on the 1/4 inch Tygon tubing coming out of the Top Collar to isolate the samples from ambient conditions. Following the HPT survey the SHA was packaged as radiation material and transported back to a custody secure RMA at WSCF where it was disassembled the following day. The in-line filters were transported to $222-\mathrm{s}$ for analysis.

The next several sampling events were scheduled in C-farm and therefore the ISVs was secured and left inside the farm.

\subsection{RADIATION SCREENING}

Radiological screening results are used to determine (1) if the samples must be shipped as radioactive or nonradioactive in accordance with $U$. $S$. Department of Transportation (DOT) regulations and (2) if the samples meet the laboratory acceptance criteria. 
HNF - SD - WM - RPT - 248，Rev . 0

The DOT limits for shipping a nonradioactive sample are 2000 combined $\mathrm{pCi} / \mathrm{g}$ of beta-gamma activity and alpha activity. Samples exceeding these DOT Iimits may be shipped as radioactive material if the samples do not exceed the following laboratory acceptance criteria:

PNNL: Beta-gamma activity $<15 \mathrm{pCi} / \mathrm{g}$ of sample media. Alpha activity $<5 \mathrm{pCi} / \mathrm{g}$ of sample media.

The sample media was not filtered for radiological particulates. The idea of unfiltered samples was to provide better analytical data for the laboratories. The samples were released for shipment based on a the analytical results of the series of two filters and tritium trap collected through one of the $1 / 4$ inch flexible lines. Based on the radiological results for the filters and tritium trap it is believed that the same concentration of radiological contaminates passed through the other 13 lines. The filters were analyzed by 222 -S Laboratory. Based on the analytical results provided in Table 1 the samples were shipped to PNNL and delivered to J. L. Julya. The VT scientists use the activity results in Table 1 to calculate $\mathrm{pCi} / \mathrm{g}$ of sample media. The VT maintains this information in the project-specific file.

Table 1. Radionuclide Analysis Results.

\begin{tabular}{|l|c|c|c|}
\hline \multicolumn{1}{|c|}{ Filter } & $\begin{array}{c}\text { Sample } \\
\text { Identifier }\end{array}$ & $\begin{array}{c}\text { Activity Results } \\
\text { (pCi/sample) }\end{array}$ & $\begin{array}{c}\text { Activity } \\
\text { (pCi/L of tank gas) }\end{array}$ \\
\hline Upstream filter & S6065-A21.OU1 & $\begin{array}{c}\text { Total Alpha }=<.346 \\
\text { Total Beta }=<2.13 \\
\text { GEA = <detectable }\end{array}$ & $\begin{array}{c}=<.346 \\
=<2.13 \\
=<\text { detectable }\end{array}$ \\
\hline Downstream filter & S6065-A22.OD1 & $\begin{array}{c}\text { Total Alpha }=<.346 \\
\text { Total Beta }=<1.27 \\
\text { GEA = <detectable }\end{array}$ & $\begin{array}{c}=<.346 \\
=<1.27 \\
=<\text { detectable }\end{array}$ \\
\hline Tritium Trap & S6065-A03.OT1 & Total Activity=<3.29 & $=<$ detectable \\
\hline
\end{tabular}

NOTES:

The samples are nonradioactive. These results were evaluated against laboratory acceptance criteria and DOT limits.

${ }^{2} \mathrm{All}$ less than $(<)$ values represent the minimum detection limits at Iaboratory $222-\mathrm{S}$. filters.

Numbers based on 1 liter for the total volume of tank vapor through the

\subsection{SAMPLE CHAIN OF CUSTODY: RECEIPT, STORAGE, AND SHIPMENT}

All sorbent trains, TSTs, and SUMMA" canisters received from PNNL are kept in a custody locked storage area maintained by SML. Sorbent trains and TSTs were maintained at $4 \pm 2{ }^{\circ} \mathrm{C}$ in a refrigeration unit. SUMMA canisters were stored in the same locked storage area, but were not refrigerated. The sample media was picked up from PNNL by SAS and transported in a government vehicle to a custody locked storage area. Appendix C lists the sample identifiers, sample types, and $C O C$ form numbers for the sampling event.

From the time that samples are received by SAS until they are shipped back to the analytical laboratory, all COCs are maintained by SAS in accordance with WHC-IP-1127-1.3, Chain-of-Custody/Special Analysis Request for RCRA and CERCLA Protocol Samples (WHC 1995a). 


\subsection{QUALITY ASSURANCE AND CONTROLS}

\subsection{CLEANLINESS OF SYSTEM}

Immediately prior to sampling of SST 241-C-201, the ISVS manifold was purged with ambient air for 5 minutes at $1 \mathrm{~L} / \mathrm{min}$. After this purge an ambient air SUMMA" sample was drawn through the ISVS manifold and the $1 / 4$ inch SUMMA" sampling line. A second ambient air SUMM" sample was collected 10 meters upwind from the tank breather filter. The ambient air samples were then collected to confirm by laboratory analysis that the Isvs sampling manifold was free of trace organic contaminants (or to determine which contaminants were present and at what concentration). For further details, refer to WHC-IP-1127-4.8 (WHC 1995b) and the project-specific file located with the VT.

\subsection{INSTRUMENT CALIBRATION}

The ISVS uses mass flow meters to measure the flow rate and totalizers to measure the total volume of sample vapor drawn through the sample media. Errors associated with the mass flow meters and totalizers were determined by the Westinghouse Hanford Company (WHC) Standards Laboratory before the SST 241-C-201 sampling event. Duration of flow are specified by the analytical laboratories that supply and analyze the sorbent traps.

Due to calibration discrepancies, the mass flow measurements for this sampling event may have an error of $6 \%$ to $14 \%$. A detailed description of this discrepancy can be found in internal memo 75820-96-028.

Table 2. Calibration Data.

\begin{tabular}{|c|c|c|c|}
\hline Element & Calibration Date & Expiration Date & $\begin{array}{l}\text { WHC Standards } \\
\text { Laboratory Code }\end{array}$ \\
\hline $\begin{array}{c}\text { Rotameter AALBORG } \\
102-05\end{array}$ & $8 / 8 / 95$ & $8 / 8 / 96$ & $518-28-13-001$ \\
\hline $\begin{array}{c}\text { Digital } \\
\text { Thermometer HH22 }\end{array}$ & $1 / 11 / 96$ & $1 / 11 / 97$ & $518-79-06-003$ \\
\hline $\begin{array}{c}\text { Vacuum Gauge } \\
\text { ASHCROFT }\end{array}$ & $8 / 7 / 95$ & $8 / 7 / 96$ & $518-31-05-003$ \\
\hline $\begin{array}{c}\text { Headspace } \\
\text { Thermocouple }\end{array}$ & $5 / 31 / 96$ & $5 / 31 / 97$ & $518-78-02-010$ \\
\hline $\begin{array}{c}\text { Mass Flowmeters } \\
\text { Sierra } 822-13 \text {-OV1 } \\
\text { FM-1/FT-1 }\end{array}$ & $8 / 8 / 95$ & $8 / 8 / 96$ & $518-28-03-015$ \\
\hline $\begin{array}{c}\text { Mass Flowmeters } \\
\text { Sierra } 822-13-\text { OV1 } \\
\text { FM-2/FT-2 }\end{array}$ & $8 / 8 / 95$ & $8 / 8 / 96$ & $518-28-03-016$ \\
\hline $\begin{array}{c}\text { Mass Flowmeters } \\
\text { Sierra } 822-13-\text { OV1 } \\
\text { FM-3/FT-3 }\end{array}$ & $8 / 8 / 95$ & $8 / 8 / 96$ & $518-28-03-017$ \\
\hline $\begin{array}{c}\text { Mass Flowmeters } \\
\text { Sierra } 822-13 \text {-OV1 } \\
\text { FM-4/FT-4 }\end{array}$ & $8 / 8 / 95$ & $8 / 8 / 96$ & $518-28-03-018$ \\
\hline
\end{tabular}


Instruments located in the ISVS are calibrated on an annual basis at the WHC Standards Laboratory. ISVS instrumentation calibration data, maintained in files by the VT, are summarized in Table 2. According to the calibration schedule shown in Table 2 , all instrumentation was within its calibration period during the SST 241-C-201 sampling event.

The totalizers were calibrated in conjunction with the mass flow meters and the calibration data is summarized in Table 3.

Table 3. Totalizer Calibration Data.

\begin{tabular}{|c|c|c|c|c|c|c|c|}
\hline Number & $\begin{array}{c}\text { Calibration } \\
\text { Date }\end{array}$ & $\begin{array}{c}\text { Expiration } \\
\text { Date }\end{array}$ & $\begin{array}{c}\text { Flow Rate } \\
\text { (stdcm }\end{array}$ (min) $^{3}$ & $\begin{array}{c}\text { Time } \\
\text { (min) }\end{array}$ & $\begin{array}{c}\text { Calc. } \\
\text { Total }\end{array}$ & UUT & Deviation \\
\hline $\begin{array}{c}3494-1 \\
\text { FT-1 }\end{array}$ & $8 / 8 / 95$ & $8 / 8 / 96$ & 247.1 & 5.833 & 1441.2 & 1500 & $3.9 \%$ \\
\hline $\begin{array}{c}3494-2 \\
\text { FT-2 }\end{array}$ & $8 / 8 / 95$ & $8 / 8 / 96$ & 253.8 & 7.065 & 1793.1 & 1800 & $0.4 \%$ \\
\hline $\begin{array}{c}3494-3 \\
\text { FT-3 }\end{array}$ & $8 / 8 / 95$ & $8 / 8 / 96$ & 262.7 & 5.081 & 1334.7 & 1300 & $2.6 \%$ \\
\hline $\begin{array}{c}3494-4 \\
\text { FT-4 }\end{array}$ & $8 / 8 / 95$ & $8 / 8 / 96$ & 25.2 & 5.186 & 1302.8 & 1300 & $0.2 \%$ \\
\hline
\end{tabular}

\subsection{BLANK SAMPLES}

Trip blanks are samples that accompany the sample media from the point of generation through sample analysis. They are transported to the field with the sample collection media but remain unopened during the sampling event. Analysis of trip blanks is used to assess cross-contamination of sample media during field transport and storage.

Field blanks are sampling devices similar to trip blanks. They are prepared and handled in the same manner as the sampling media, but no tank vapors are drawn through them.

Spiked blanks are prepared as regulax sampling media but also contain a known amount of special analyte. Tank vapors are drawn through these blanks and they are handled and analyzed just like any other sample. Analysis of the spiked blanks is used to evaluate potential sample loss during shipment or storage.

Ambient blanks are samples of ambient air collected at the sampling location. Analysis of ambient blanks is used to assess contamination that may be present in the atmosphere or in the transfer tubing or sampling manifold of the ISVS immediately prior to sampling operations.

\subsection{ANOMALIES}

The VT used the Sampling and Analysis Plan and WHC-IP-1127-4.8, Vapor Sampling of Waste Tanks Using In Situ Vapor Sampling System (ISVS), (1995b) to guide the sample collection. Anomalies noted during the sample collection are briefly described below. 
HNF - SD-WM-RPT-248, Rev, 0

This was the first job to use the "Top Hat" adapter, which converts a 12 inch riser to 4 inch PVC pipe to allow easier insertion of the sample Assembly. No problems were encountered with the use of the "Top Hat".

Prior to the start of sorbent sampling, it was discovered that some of the sample lines were missing labels. The labels had most likely fallen off due to the heat and moving the tube bundle around. The result is that lines 4,5 , 7 , and 8 could not be identified. Non-labeled sample lines were

$\begin{array}{lll}4 & \mathrm{NH} 3 / \mathrm{NOx} / \mathrm{H} 20 & 2,000 \mathrm{sCC} \\ 5 & \mathrm{NH} 3 / \mathrm{NOx} / \mathrm{H} 20 & 2,000 \mathrm{sCC} \\ 7 & \mathrm{TST} & 200 \mathrm{sCC} \\ 8 & \mathrm{TST} & 200 \mathrm{sCC}\end{array}$

The labeled NH3 and TST lines were samples as indicated in the SAP. This provided two NH3 and two TST samples at the desired volume. All four nonlabeled lines were samples at a flow rate of $220 \mathrm{sccm}$ for a total of 1,000 $\mathrm{scc}$. The actual volumes ranged from $1000 \mathrm{scc}$ to $1002 \mathrm{scc}$. This was five times the volume desired in the TST and half the volume desired in the NH3 sorbents, but still allows for the chemists to calculate headspace concentrations.

These anomalies were also noted on the sample log sheets in Appendix $A$.

\subsection{REFGRENCES}

49 CFR 100-177, 1992, "Transportation," Code of Federal Regulations, as amended.

Blanchard, R. J., 1996a, System Design Description for the In Situ Vapor Sampling System, WHC-SD-WM-SDD-068 Rev. 0, Westinghouse Hanford Company, Richland, Washington.

Washington.

Homi, C. S., 1996b, Vapor Sampling and Analysis Plan, WHC-SD-WM-TP-335 Rev. 2A, Westinghouse Hanford Company, Richland, Washington.

Trible, T. C., Viswanath, R. S., 1996C, Recommendation concerning the ISVS/VSS comparison study data with respect to calibration errors in Mass flow monitors and controllers, (internal memo 75820-96-028 to L.D. Pennington, August 28), Westinghouse Hanford Company, Richland, Washington.

WHC, 1995a, Chain-of-Custody/Special Analysis Request for RCRA and CERCLA Protocol Samples, Procedure WHC-IP-1127-1.3, Rev. 1, Westinghouse Hanford Company, Richland, Washington.

WHC, 1995b, Vapor Sampling of Waste Tanks Using In Situ Vapor Sampling System (ISVS), Procedure WHC-IP-1127-4.8, Westinghouse Hanford Company,

Richland, Washington. 
HNF-SD-WM-RPT-248，Rev. 0

This page intentionally left blank. 
HNF-SD-WM-RPT-248，Rev. 0

APPENDIX A

SAMPLE LOG SHEETS

A- 1 
HNF-SD-WM-RPT-248，Rev. 0

This page intentionally left blank.

A-2 
HNF - SD - WM-RPT - 248， Rev. 0

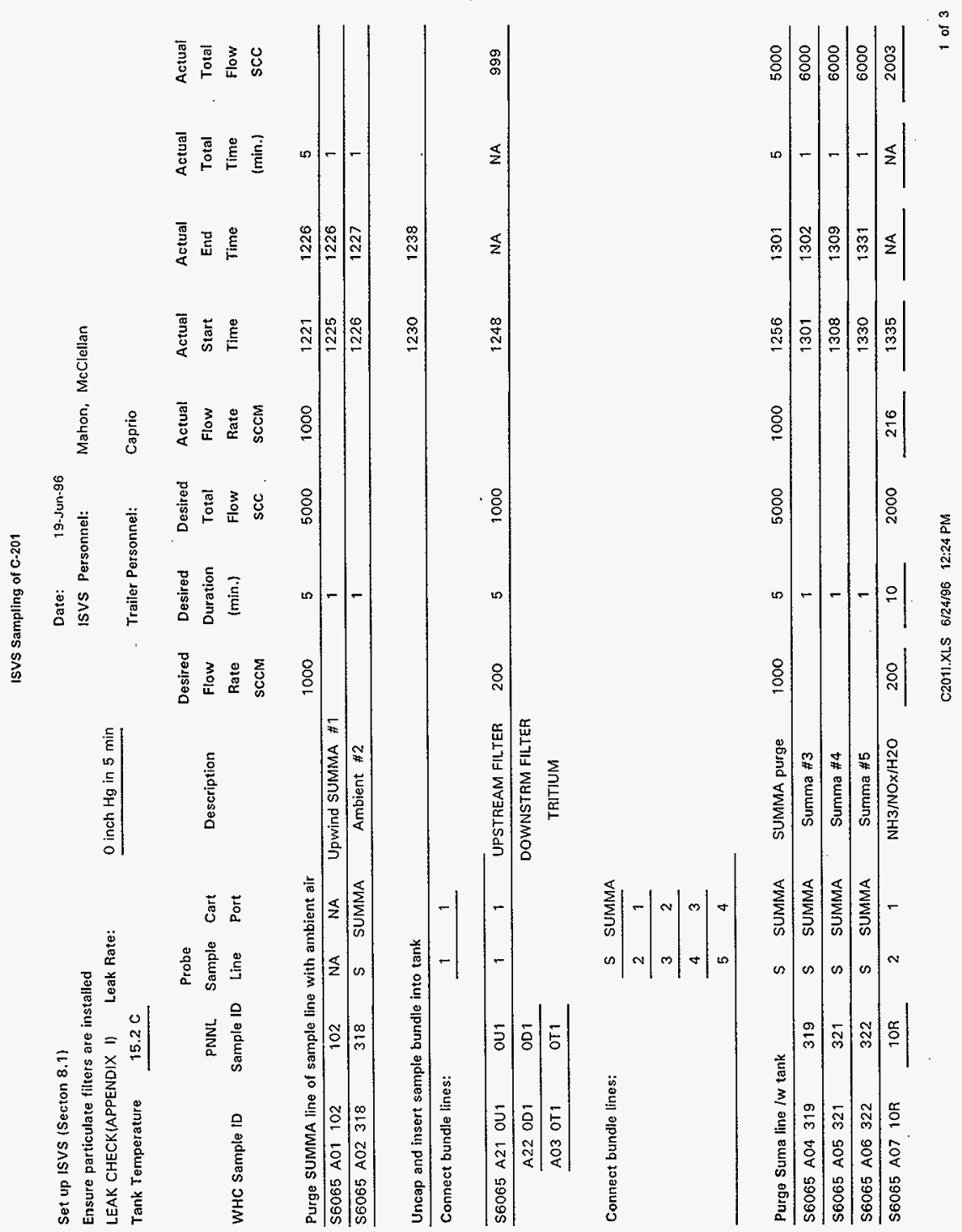




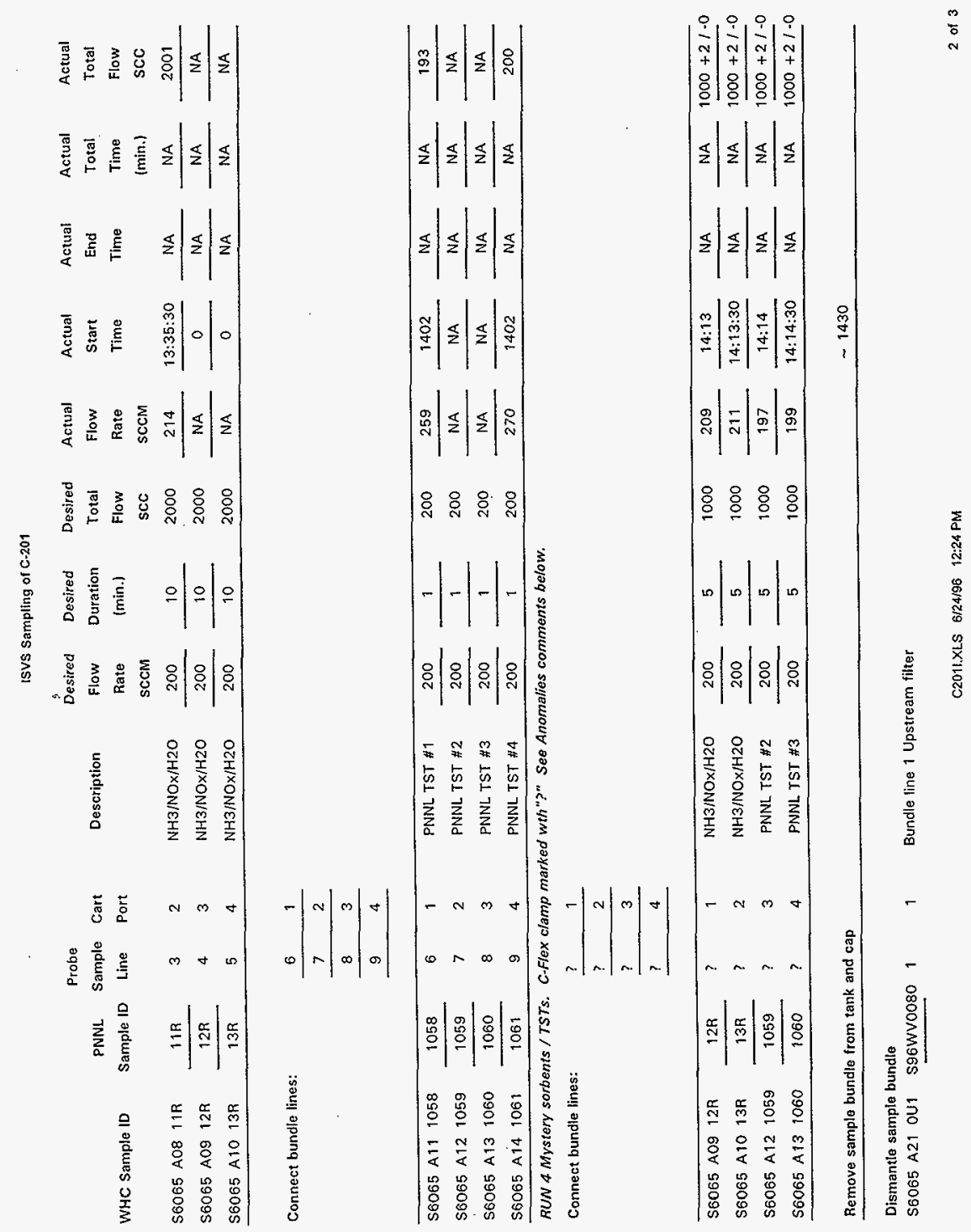


ISVS Sampling of C-201

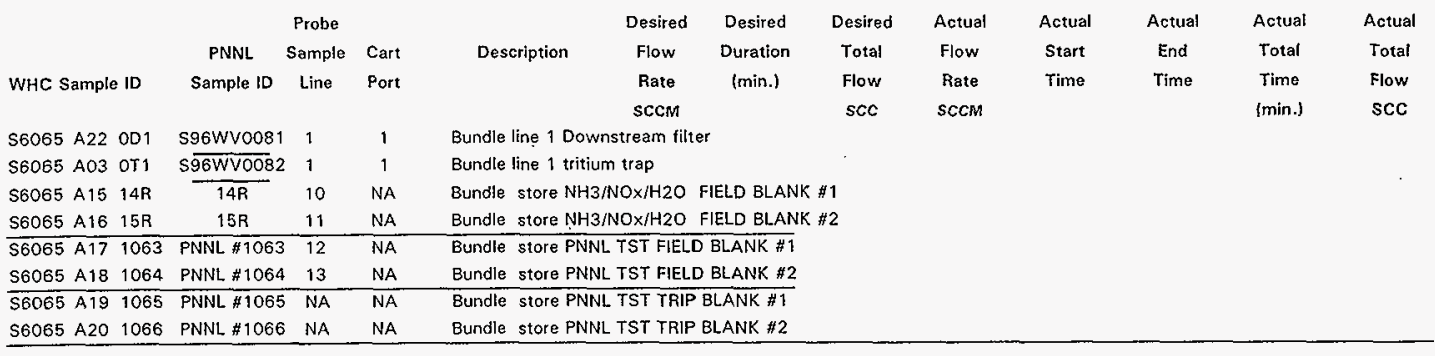

Remove tilters from cart manifold ports $1,2,3,4$, and SUMMA to release cart.

BUNDLE TOTAL TANK GAS USED DURING SAMPLING RUNS (Liters)

28.40

Note: SCCM for the ISVS is reported at 760 torr, $21 \mathrm{C}$

ANOMALIES

S6065-A09.12R

S6065.A10.13R

1310 It was observed that some of the labels had fallen off of the Tygon lines. By process of elimination, it was determined that the labels had fallen

\$6065-A12.1059 for a total volume of $1,000 \mathrm{scc}-0 /+2 \mathrm{scc}$. New checksheets were added labeled "Mystery Lines". The logic was to split the difference between the 2,000 scc

S6065-A13.1060

for NH3 traps and the 200 scc for TSTs. 
Note: \#VALUE! $=<$ Deteclable

S6065-A21.OU1 I S96WWO080 PARALLEL UPSTREAM FILTER TOTAL VOLUME ALPHA

BETA.

GEA. $\quad \cos 60$

Cs-134

Cs-13?

Eu-152

Eu.154

Eu-155

\begin{tabular}{|c|c|c|}
\hline \multirow{9}{*}{$\begin{array}{r}\text { Liters } \\
1.00\end{array}$} & pCi / filler & pCi / liter \\
\hline & $<0386$ & \#VALUU! \\
\hline & $<2.13$ & \#VALLUE! \\
\hline & $\Leftrightarrow 11.6$ & $<$ Deteclable \\
\hline & $<9.605$ & $<$ Deteclable \\
\hline & $<25.98$ & < Deteclable \\
\hline & $<55.29$ & < Detectable \\
\hline & $<31.4$ & < Detectable \\
\hline & $<30.16$ & $<$ Delectable \\
\hline
\end{tabular}

S6065-A22.0D1 / S96WW0081 PARALLEL DOWNSTREAM FILTER TOTAL VOLUME ALPHA BETA

GEA -

$$
\begin{array}{r}
\text { Co-60 } \\
\text { Cs-134 } \\
\text { Cs-137 } \\
\text { Eu-152 } \\
\text { Eu-154 } \\
\text { Eu-155 }
\end{array}
$$

Liters $\mathrm{pCi} /$ filler

pCi / titer

100

$\begin{array}{lr}<0.346 & \text { \#NALUE! } \\ <1.27 & \text { \#NALUE! } \\ <9.333 & \text { < Detectable } \\ <8.522 & \text { < Detectable } \\ <24.99 & \text { < Detectable } \\ <30.93 & \text { < Delectable } \\ <27.61 & \text { < Delectable }\end{array}$

S6065.A03.017 / S96WV0082

SAMPLE EXPOSURE ANALYSIS, USING TOTAL OF BOTH UPSTREAM AND DOWNSTREAM FILTER ANALYSIS AS POSSIBLE EXPOSURE LEVEL

\begin{tabular}{|c|c|}
\hline TOTAL VOLUME PER SAMPLE & 2.00 Lilers \\
\hline \multicolumn{2}{|l|}{ Tritium per SAMPLE } \\
\hline NH3 (5 gram) & \# VALUE! PCI per gram \\
\hline H2O (s gram) & \#NALUE! pCi pe: gram \\
\hline \multicolumn{2}{|l|}{ ALPHA per SAMPLE } \\
\hline NH3 (5 gram) & \#VALUE! pCi per gram \\
\hline $\mathrm{H} 2 \mathrm{O}$ (5 gram) & NALUE! pCl per gram \\
\hline \multicolumn{2}{|l|}{ BETADET SAMPLE } \\
\hline NH3 (5 gram) & \#VALUE! pCi per gram \\
\hline H2O (5 gram) & \#ALUE! PCi per gram \\
\hline \multicolumn{2}{|l|}{ GEAPE SAMPLE CS-137 } \\
\hline NH3 (5 gram) & \#VALUE! PCI per gram \\
\hline H2O (5 gram) & \#NALUE! PCi per gram \\
\hline
\end{tabular}

$=$ BETA and ALPMA Less than DOT shipping limits

Total Apha ( $(\mathrm{C} \mathrm{C} / \mathrm{f} / \mathrm{iter})=$

Total GEA Cs-137 (pCi/liler) = \#VALUE!

TST SAMPLING Used $4.5 \mathrm{~g}$ for TST mass

TOTAL VOLUME PER SAMPLE

Tritum per Sample

TST 4.5 gram) \#ALUEl pCiper gram

ALPHA per Sample

TST (4.5 gram)

\#VALUEF pCiper gróm

TST ( 4.5 gram)

TST (4.5 gram)

\#NALUEI pCi per gram

\#VALUEI pCiper gram

\section{SUMMA SAMPLING}

TOTAL VOLUME PER CANISTER

Tritium PER SAMPLE

ALPHA PER SAMPLE

GEA PER SAMPLE Cs-137
6 Liters (air \& $300 \mathrm{~K}, 1$ ber $=1.161 \mathrm{gl}$ ) \#VALUE! pCI per gram

\#VALUE! PCi pri gram

\#ALUE! pCI per gram 
HNF - SD -WM-RPT-248，Rev. O

This page intentionally left blank. 
HNF-SD-WM-RPT-248, Rev, 0

APEENDIX B

AMBIENT CONDITIONS

B-1 
FNF - SD-WM-RPT-248, Rev . 0

This page intentionally left blank.

B-2 
WEATHER DURING ISVS SAMPLING OF 241-C-201

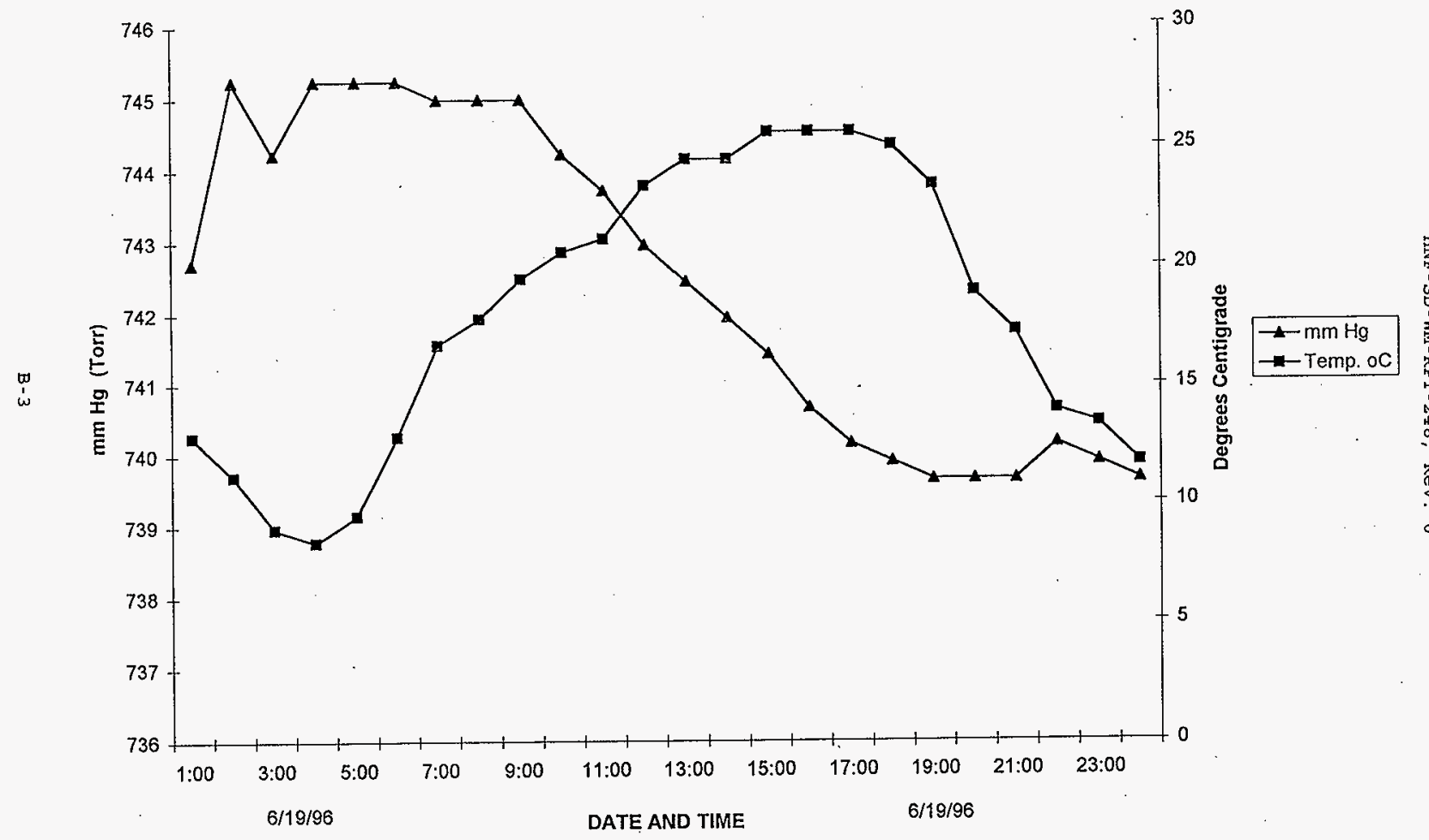


HNF-SD-WM-RPT-248，Rev. 0

This page intentionally left blank. 
HNF -SD-WM-RPT-248，Rev. 0

APPENDIX C

CHAIN-OF-CUSTODY FORMS

C- 1 
HNF - SD - WM-RPT-248, Rev . 0

This page intentionally left blank. 


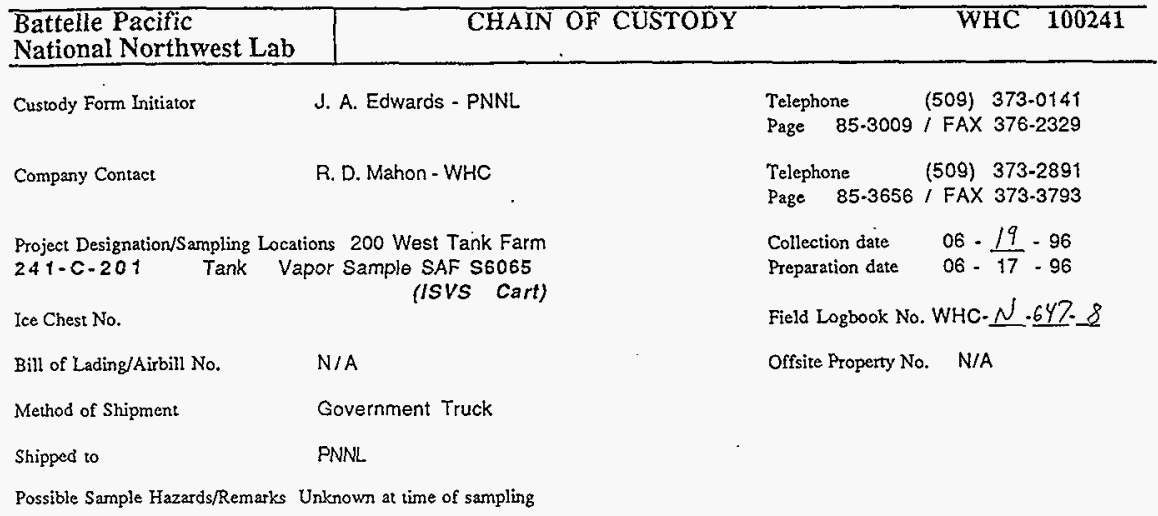

S6065 - A01 . 102

$\mathrm{S} 6065$ - A02 . 318

S6065 - A04 . 319

S6065 - A05 . 321

$\$ 6065-A .06 .322$
Collect Ambient Air Sample SUMMA \#1

Collect Ambient Air Sample SUMMA \#2 (through tube bundle)

Collect SUMMA \#3

Collect SUMMA \#4

Collect SUMMA \#5

\begin{tabular}{|c|c|c|c|c|c|}
\hline [ ] Field Transfer of Custody & \multirow{2}{*}{\multicolumn{3}{|c|}{ (X) Chain of Possession }} & \multicolumn{2}{|c|}{ (Sign and Print Names) } \\
\hline Relinquished By & & & & Date & Time \\
\hline 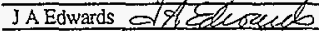 & $06-17-96$ & $\angle 400$ & 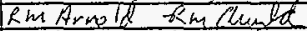 & $06 \cdot 17-96$ & 1400 \\
\hline 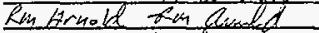 & $06-17-96$ & 1500 & 20 Mathon & $06-17-96$ & 1500 \\
\hline RDMShon RD nulion & $06-24-96$ & 1140 & CS CAPRID & $0_{6}-2 y-46$ & 1140 \\
\hline GS CAPREO YS QIL $D$ & $6-24-96$ & 1322 & JuInel & $6-24-96$ & 1322 \\
\hline
\end{tabular}

Comments:

Final Sample Disposition

PNNL (only) Checklist Media iabeled and checked?

Letter of instruction?

Media in good condition?

COC info/signatures complete?

Rad release sijckers on samples?

Activity report from $222 S$ ?

RSR/release? (a $\leq 100 / 3 \leq 400 \mathrm{pCi} / \mathrm{g}$ )

COC copy for LRB, RIDS filed?

(WHC-SD-WM-TP-335, REV. 2, Table 2b)

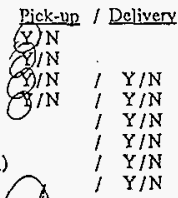

POC
Comments:

(Revised 05/30/96 PNNL) 


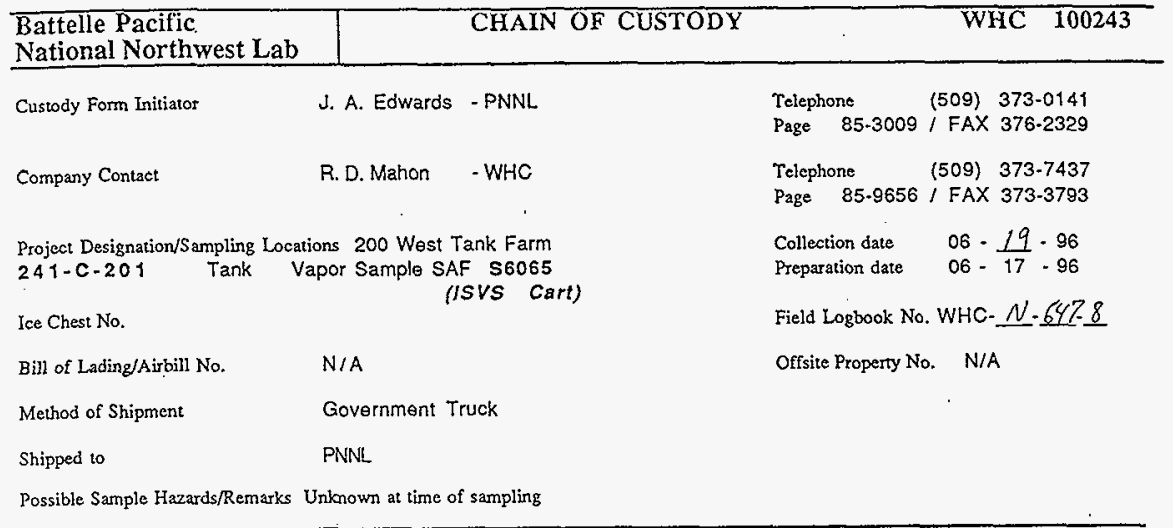
Sample Identification

$\begin{array}{ll}\mathrm{S} 6065-\mathrm{A} 07.10 \mathrm{R} & \text { Collect } \mathrm{NH} / \mathrm{NO}_{\mathrm{X}} / \mathrm{H}_{2} \mathrm{O} \text { Sorbent Trap } \\ \mathrm{S} 6065-\mathrm{A} 08.11 \mathrm{R} & \text { Collect } \mathrm{NH} / \mathrm{NO}_{\mathrm{X}} / \mathrm{H}_{2} \mathrm{O} \text { Sorbent Trap } \\ \mathrm{S} 6065-\mathrm{A} 09.12 \mathrm{R} & \text { Collect } \mathrm{NH} / \mathrm{NO}_{\mathrm{X}} / \mathrm{H}_{2} \mathrm{O} \text { Sorbent Trap } \\ \mathrm{S} 6065-\mathrm{A} 10.13 \mathrm{R} & \text { Collect } \mathrm{NH} / \mathrm{NO}_{\mathrm{X}} / \mathrm{H}_{2} \mathrm{O} \text { Sorbent Trap }\end{array}$

S6065 - A15 . 14R S6065 - A16. 15R
Open, close and store $\mathrm{NH} 3 / \mathrm{NO}_{\mathrm{X}} / \mathrm{H}_{2} \mathrm{O}$ field blank \#1 Open, close and store $\mathrm{NH}_{3} / \mathrm{NO}_{\mathrm{X}} / \mathrm{H}_{2} \mathrm{O}$ field blank $\# 2$

\begin{tabular}{|c|c|c|c|c|c|}
\hline \multicolumn{2}{|l|}{ Field Transfer of Custody } & Chain of Possession & \multicolumn{3}{|c|}{ (Sign and Print Names) } \\
\hline Relinquished By & Date & Time & Received By & Date & Time \\
\hline GW Dennis $A . \omega .1 S=$ & $06-17.96$ & 0915 & JA Edwards $\rightarrow \mathrm{At}$ elweech & $06-17-96$ & 0915 \\
\hline 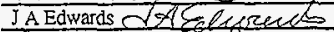 & $06-\overline{8}-96$ & 1041 & GS coetio $\mathrm{HS}$ Cal $\rightarrow$ & $06-18-96$ & 1041 \\
\hline$\angle S \angle A P R I O$ MS $\angle C D=$ & $106-24-76$ & 1322 & lant $x$ lube. & $06-7 y-96$ & 1323 \\
\hline & & & & & \\
\hline & & & & & \\
\hline & & & & & \\
\hline
\end{tabular}

Comments:

Final Sample Disposition

$\begin{array}{ll} & \text { PNNL (only) Checklist } \\ \text { Media labeled and checked? } & \text { Letter of instruction? } \\ 0 & \text { Media in good condition? } \\ 0 & \text { COC info/signatures complete? } \\ 0 & \text { Rad release stickers on samples? } \\ \text { Activity report from } 222 S ? \\ \text { RSRrelease? (a } \leq 100 / 3 \leq 400 \mathrm{pCi} / \mathrm{g}\end{array}$

(WHC-SD-WM-TP.335, REV. 2, Table 2b) A-6000-407 (12/92) WEF061

\begin{abstract}
/ Delivery
I $\mathrm{Y} / \mathrm{N}$

I $\mathrm{Y} / \mathrm{N}$

I $\mathrm{Y} / \mathrm{N}$

I $\mathrm{Y} / \mathrm{N}$

I $\mathrm{Y} / \mathrm{N}$

I $\mathrm{Y} / \mathrm{N}$
\end{abstract}

POC
Comments:

1310hes 1954N96. The labels had tallen off of lipes $4,5,7,8$. The four mytory Lihes were ranat $200 \mathrm{sec}$ tor a total volume of $1000 \mathrm{sec}+2 / \mathrm{Horec}$. This affects samples S6065-A09.12R and $56065-A 10,13 R$ by decreasing voluma to $1,000 \mathrm{sec}+2,-6 \sec . \pi, 5 m 24 \pi, 196$

(Revised 05/30/96 PNNL) 


\begin{tabular}{l|lll}
\hline Battelle Pacific & CHAIN OF CUSTODY & WHC & 100242 \\
Northwest Laboratory & & \\
\hline
\end{tabular}

Custody Fom Initiator

Company Contact

J. A. Edwards - PNL

R. D. Mahon - WHC

Project Designation/Sampling Locations 200 West Tank Farm 241-C-201 Tank

Vapor Sample SAF $\$ 6065$

(ISVS Cart)

Ice Chest No.

Ertco Hi/Lo thermometer No.

Bill of Lading/Airbill No.

Method of Shipment

Shipped to

Possible Sample Hazards/Remarks Unknown at time of sampling

N/A
Government Truck

WHC.

\begin{abstract}
Telephone (509) 373-0141
Page 85-3009/P8-08/FAX.376-0418

Telephone (509) 373-7437

Page $\quad 85-9656 / 53-27 /$ FAX 373-7076
\end{abstract}

Collection date $\quad 06.19 .96$

Preparation dete $\quad 06-17-96$

Field Logbook No. WHC. N. 647.8

PNL-T.006

Offsite Property No. N/A

\section{- Sample Identification}

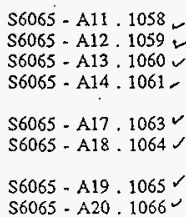

$\$ 6065$ - A11 . 1058

\$6065 - A12 . $1059 \longleftarrow$

\$6065 - A13, 1050

$\$ 6065$ - A17 . 1063 V

S6065 - A20 $1066^{\circ}$
PNL Triple Sorbent Trap (TST) Sample \# 1

PNL TST Sample \# 2

PNL TST Sample \# 3

PNL TST Sample \# 4

Open, close \& store TST Field Blank \# 1

Open, close \& store TST Field Blank $\# 2$

Store TST Trip Blank \#1

Store TST Trip Blank \#2

\begin{tabular}{|c|c|c|c|c|c|}
\hline ( ) Field Transfer of Custody & & X 1 Chair & f Possession & nd Print Names & \\
\hline Relinquished $\mathrm{BV}$ & Date & Time & Received By & Date & Time \\
\hline 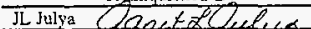 & $06-\angle 7.96$ & 1255 & JA Edwards dAfolcenec है & $06-17-96$ & 1255 \\
\hline 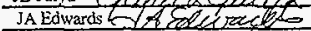 & $06-2796$ & 1400 & Ru Aruald Xin de dx & $06-17-96$ & 1400 \\
\hline Eunferneld fen fruolel & $06-17-36$ & 1500 & Rdmahan RD nouloon & $06-17-96$ & 1500 \\
\hline RD Makom 180 man & $06-24-4 t$ & 1140 & CS, CAPLIO $\mathrm{CO} 2$ & $06-24-96$ & $1 / 40$ \\
\hline GS CAPRIO $M A$ COLI & $\alpha_{c}-24-96$ & 1320 & \pm 2 & $06.24-96$ & 1320 \\
\hline & & & & & \\
\hline & & & & & \\
\hline
\end{tabular}

Comments:

PNL (only) Checklist

Media labeled and checked?

Letter of instruction?

Media in good condition?

$\mathrm{COC}$ info/signatures complete?

Sorbents shipped on ice? $\left(<5^{\circ} \mathrm{C}\right)$

Hi/Lo therrnometer - Keep upright!

$\mathrm{Hi}$ Lo thermometer

Rad release stickers on samples?

Activity report from $222 S$ ?

COC copy for LRB, RIDS filed?

Final Sample Disposition

1310 hrs 19 JuN 96 . The labels had fillen off

Bick-un / Delivery

g) $N$

(6) $\mathrm{N}$

$\mathrm{X} N, \mathrm{Y} / \mathrm{N}$

ZIN $/ Y / N$

Q IN I YIN

$\mathrm{CV}_{\mathrm{N}}$

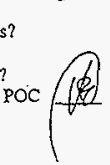

I $\mathrm{Y} / \mathrm{N}$

$1 \mathrm{Y} / \mathrm{N}$

I $\mathrm{Y} / \mathrm{N}$

$(\mathrm{Y} / \mathrm{N}$

POC commerits: of lines $4,5,7,8$. The four mystory lines were mn at 200 sce for a tatal volume of

1,000 sec $+2 / 1$ osce. This affects samples $56065-A / 2.1059$ and $S 6065-A / 3.1060^{\circ}$ by 1. Cooler Temperature Status _ I incressing $1 \mathrm{Hi}-23^{\circ} \mathrm{C} / \mathrm{Lo}-23^{\circ} \mathrm{C}$ (pick up at PNL to WHC) $\mid \mathrm{vo} / \mathrm{ume}$ ) iHi $77^{\circ} \mathrm{C} / \mathrm{LO}-23^{\circ} \mathrm{C}$ (delivery at WHC from PNL) 1, 1000

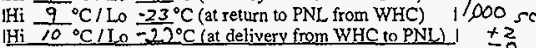
24 Jun 96 गु2n (Revised 06/21/95 PNL) 
HNF - SD-WM-RPT-248, Rev. 0

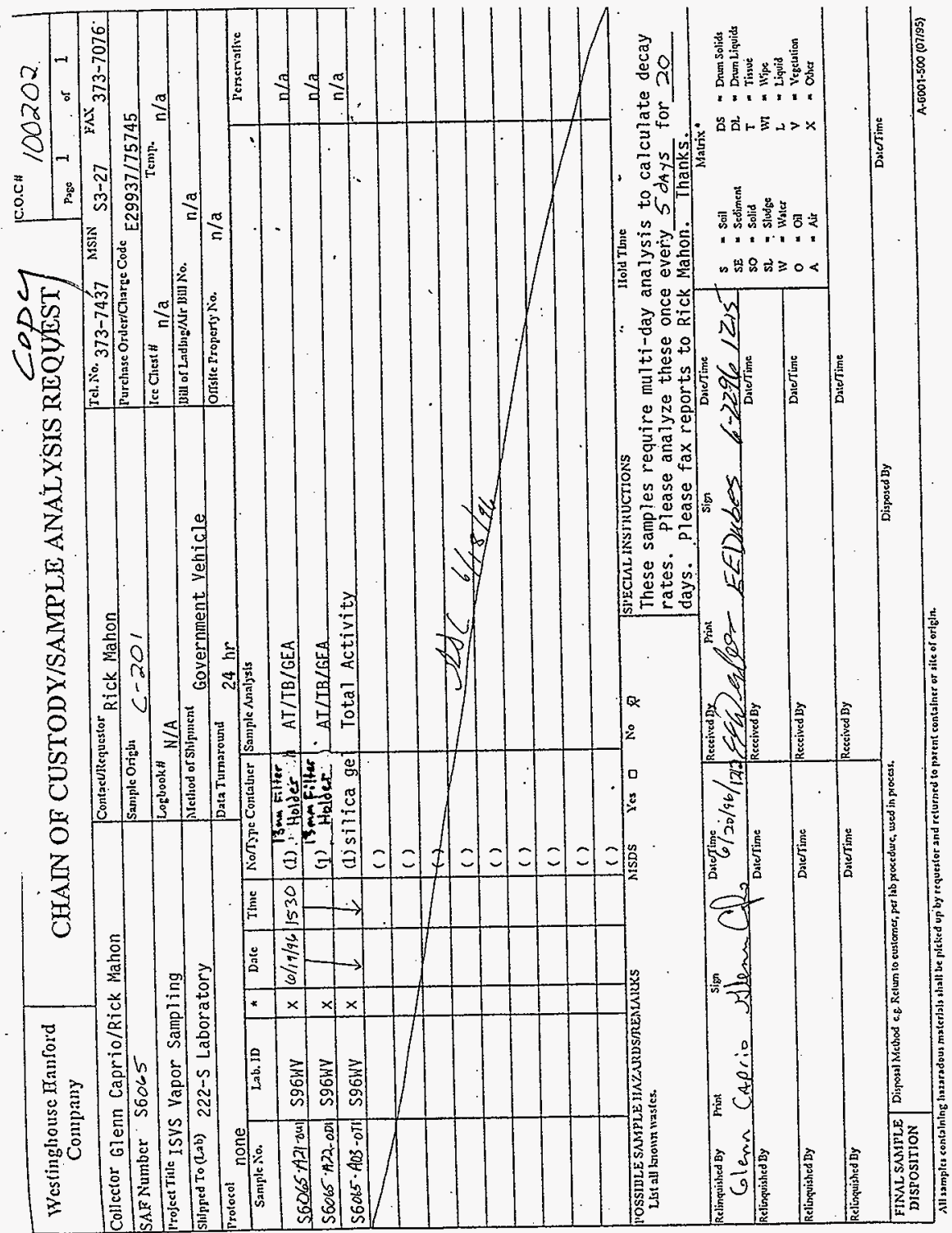




\section{DISTRIBUTION SHEET}

\begin{tabular}{|c|c|c|c|c|c|}
\hline \multirow{2}{*}{$\begin{array}{l}\text { To } \\
\text { Distribution }\end{array}$} & \multirow{2}{*}{\multicolumn{3}{|c|}{$\begin{array}{l}\text { From } \\
\text { Special Analytical Support, } \\
\text { Numatec Hanford }\end{array}$}} & \multicolumn{2}{|l|}{ Page 1 of 1} \\
\hline & & & & \multicolumn{2}{|l|}{ Date $8 / 7 / 97$} \\
\hline \multirow{2}{*}{\multicolumn{4}{|c|}{$\begin{array}{l}\text { Project Title/Work Order } \\
\text { VAPOR AND GAS SAMPLIN }\end{array}$}} & \multicolumn{2}{|c|}{ EDT No. $62 / 267$} \\
\hline & & & & \multicolumn{2}{|l|}{ ECN No. } \\
\hline Name & MSIN & $\begin{array}{c}\text { Text } \\
\text { With All } \\
\text { Attach. }\end{array}$ & Text Only & $\begin{array}{l}\text { Attach.l } \\
\text { Appendix } \\
\text { Only }\end{array}$ & $\begin{array}{l}\text { EDT/ECN } \\
\text { Only }\end{array}$ \\
\hline
\end{tabular}

Lockheed Martin Hanford Company
L. L. Buckley
R2-12
$x$

Lockheed Martin Services. Inc.

Central Files

A3-88

$x$

SGN Eurisys Services Corporation

E. S. Mast

S3-90

$x$

PNNL

J. L. Huckaby

K6-80

$x$ 